\title{
The Crisis of Transition: Pier Paolo Pasolini's African Oresteia ${ }^{1}$
}

The Appunti per un'Orestiade africana $(1970)^{2}$ are the preliminary notes, in filmic form, for a projected film which Pasolini never makes. It is an audiovisual survey, made up largely of documentary footage shot in Tanzania and Uganda, of how Pasolini would go about filming the Oresteia. Pasolini explains:

I have obviously come here to film, but to film what? Not a documentary and not a feature picture. I have come to shoot some notes for a film, the Oresteia of Aeschylus, to be shot in the Africa of today, in modern Africa. ${ }^{3}$

Notes thus explores African images, panoramas and characters which would lend themselves to the mythical scenario of a filmic version of the Oresteia.

A constant in Pasolini's thinking throughout the 1960s is his equation of the Third World with the yearned-for qualities of irrational 'prehistory,' savage, innocent and pure, where one lives by the senses alone, and where nature is a dark and inexplicable force. His Notes, inspired by the Greek legend of Orestes, and Athens' transition to democracy, becomes a means by which Pasolini views post-colonial African history through the lens of mythology. It is Pasolini's attempt to depict Africa's transition to capitalism and 'civilisation.' The overall feeling of these works ${ }^{4}$ speaks for a return to an edenic state, to a prehistory. The notion of prehistory, however, is immediately problematic, as Pasolini himself states: "La preistoria avrà le sue rivincite, ci umilierà con la sua terribile, trionfante incomprensibilità... Ma che fare?" (Le poesie 51) [Prehistory will have its revenge, it will humiliate us with its terrible, triumphant incomprehensibility... But what is there to do?].

However poignant Pasolini's notion of prehistory may be, it is also problematic and contradictory: for instance, on the side of Pasolini's idealistic savagery is the reality of the horrific wars that have mutilated Africa (the Biafran and Ugandan wars), while on the side of democracy / "civilisation' is justice. In Notes, for example, in the city of Athens (represented by the Supreme Court of Dar Es Salaam), where Orestes will be judged for the murder of his mother Clytemnestra (who murdered his father Agamemnon), the god- 
dess of reason, Athena, declares:

Citizens of Athens, you will for the first time in the world judge a crime. From now on, the people will have the right to this assembly of its own. Let not anarchy nor dictatorship ever stand before you, o citizens, but let not authority be wholly banished for no one does his duty without fear. If you respect this order always, you will live at peace within your walls as no other people in the world ever have.

Athena's words of democracy, ironically, are represented as admirable (by Pasolini) as they call for necessary order and control among human beings. Not only do Athena's words establish the first lessons of democratic history, but they demonstrate a will towards intellectual clarification, another aspect of the new 'civilised' order, represented in Notes by the University of Dar Es Salaam.

The above highlights the contradiction upon which this paper will focus. On the one hand, Pasolini's dream of prehistory is questionable because of the tragic paradoxes and yet he tries to salvage it through his use of myth. On the other hand, his intense anathema of (neo-)capitalism is riddled with contradictions as some of the positive aspects of democracy cannot be ignored by Pasolini. Like the Furies are transformed, in Aeschylus' Oresteia, into the Eumenides who will rule the democratic state, Africa appears to be in some ways positively transformed by democracy: for example, the University of Dar Es Salaam is used to represent the Temple of Apollo for it is elegant and confident in design. African universities are the seat of the future local intelligentsia in the culture and learning of young African nations, and they display all the internal contradictions of those young African nations. However, this very intellectualism is tainted with the urmistakable signs of American progressive neo-capitalism which Pasolini sees as destructive of Africa's primal being. The book titles in the bookshop which Pasolini's camera scans (American Education Today; The Social Education of the Adolescent; Handbook for History Teachers in West Africa) express this contradiction.

Pasolini, the Marxist, who is drawn to the light of intellect reflected in some aspects of democracy, is at the same time drawn to the unspoken darkness hidden in Africa, to its primal human nature:

Il suo universo concresce su bipolarità archetipiche che postulano l'antitesi e la contraddizione poiché su queste fondano il loro equilibrio/squilibrio. (Santato 116) [His universe grows upon the archetypical bipolarities which postulate antithesis and contradiction since upon these are founded their balance/imbalance.]

Possibly due to the myriad of contradictions in Pasolini, Bongie sees Pasolini's encounter with the Third World as "infertile" and a "failed encounter" (191): 
his early hopes for the revolutionary potential of this prehistoric force were, by the middle of the decade, beginning to collapse in the face of an increasingly tragic awareness that modernity had already permeated every last recess of the "prehistory" he wished to valorize. (190)

Paradoxically, in the earlier Uccellacci e uccellini (1966), Pasolini was already aware of his contradictory nostalgia for "il sogno di una cosa" when, as Bongie points out, he pokes fun at a position close to his own: Courneau, a protagonist in the film, "is a bitingly sarcastic portrayal of the Western intellectual attempting to come to terms - inevitably, his own terms - with the reality of the Third World," an intellectual who, after the Second World War was "to take back, under the cover of an ostensibly progressivist ideology, the worn mantle of the "exotic subject'" (189). Or as Siciliano puts it: "One might say that in Pasolini an old cultural dream - exoticism - donned progressive clothes" (265).

This paper argues that Pasolini's angst, revealed in the contradictions and paradoxes of his ideal state, not only reflects the crisis of transition of African states (their notorious reputation with violations of human rights and yet their struggle to be bom), but possibly reveals a greater transition in a literary sense. Pasolini, it can be argued, seems to be at some kind of literary crossroads, caught between the hope he had in the Ragazzi di vita and the "politics of absence [...], the acknowledged impossibility of confrontation with the present" (Bongie 228).

Alberto Moravia, in an article entitled "Oreste a $30 \mathrm{~m}$ all'ombra" in L'Espresso, poses the question: "Why has Pasolini abandoned the realism of his novels and early films?" and concludes that "perhaps Pasolini has tried to avoid forced interpretations, forged by the practical necessities of political action, by shifting himself to a more ambiguous level" (Siciliano 331).

What is so haunting and real about Notes is that it describes the crisis of transition, and the possibility that the ideal state only lives on in the myth of Orestes. There is, therefore, no closure. Pasolini acknowledges the

scandaloso rapporto dialettico che il terzo mondo instaura col mondo industrializzato, neocapitalista o marxista. (Pasolini, in Falaschi 394).

[scandalous dialectical relationship that the third world establishes with the industrialised world, be it neo-capitalist or Marxist.]

The archaic and paternal authority of the Third World becomes the means against which to contrast the authority of all the moral and social institutions with which Pasolini clashed. The Third World becomes the new terrain, to "essere cosciente della assoluta necessità di rinnovamento, di mettere in ballo tutto, senza paura e senza rimpianti" (Golino 229) [be conscious of the absolute need to renew, to question everything, without fear and without regret]. 
His nostalgic fascination for the Third World as seen in Notes, however, is an aspect of Pasolini's work which has been largely ignored.? Furthermore, it is this fascination which inspired Pasolini's narrative itself:

a narrative propelled by dark and savage impulses that well up from the unconscious of individuals and from mankind's archaic past. History gives way to myth as the linear time of Christianity is eclipsed by what Mircea Eliade - the famous ethnologist much admired by Pasolini - calls the "eternal return" of earlier religions. (Greene 127)

Pasolini's need to find "il sentimento dell'altrove" (Il caos 149) [the sense of an elsewhere $]^{8}$ which was uncontaminated by "i guasti dello sviluppo senza progresso" (Golino 241) [the damage of development without progress] of bourgeois consumerism grew increasingly as he felt repelled by the new Italy emerging around him. This longing led his search for a myth of the past to Africa, the promised land of innocence and marginality, which Pasolini saw as the polar opposite of the 'universo orrendo' of neo-capitalism, in order to

explore the ways in which age-old habits of thought and being persist in the modern world - physically, as in Third World countries, [and to] explore the clash, the mingling, of vastly different strands of civilisation. (Greene 128)

His desire to make a modern African Oresteia is motivated by the parallels he sees between the evolution of ancient Greek civilisation and that of contemporary Black Africa. The story of the Furies is thus treated as an allegory on the modern situation of Africa. Just as the archaic moment of Greek civilisation, embodied in the Furies who hound Orestes, gave way to the democratic state ruled by the Eumenides, so too, in the last century have the African people been in the transition from an archaic to a rational mentality.

Already in 1960 Pasolini had translated Aeschylus' Oresteia ${ }^{9}$ which he saw as a victory of reason over instinct: "The irrational [...] must not be repressed (which anyway would be impossible), but simply held in check and dominated by reason, passion-producing and fertile" (Pasolini, in Siciliano 235). And in the same year, Pasolini utters his first invocation of Africa, the first seed of a new hope, in a poem entitled "Frammento alla morte":

Africa! Unica mia
alternativa.............
(Le poesie 305 ).
[Africa! My sole
alternative.............

Pasolini attempts to connect the Oresteia to Africa because, through its land and its people, Africa bears the traces of prehistory as does Greek mythology: 
"the archaic quality of Aeschylus was the anthropological prefiguration of some peasant Third World" (Siciliano 235).

What better way to represent the Furies, for example, than to portray them in the non-human guise of trees in mystical, mythical Africa. Pasolini says in Notes:

The trees, lost in the silence of the forest, are monstrous and terrible, for the terrible aspect of Africa is its solitude. They represent the monstrous forms that nature can assume, the deep and frightening silences. Irrationality is animal. The Furies are the goddesses of man's irrational moment. The Furies of the Oresteia are destined to be defeated, to disappear. Therefore they disappear as the world of the forefathers, of the ancestral world, the ancient world, and in the film, a part of ancient Africa is destined to disappear with them.

There is a sense of a profound lament for a savagery lost, and the suggestion is that the transition to post-colonial democracy produces this loss. What Pasolini attempts to show is that the assumption of a new consciousness must and does create a spiritual crisis.

In the light of this, there is a strong similarity to Edipo re (1967) and Medea (1969) in that both these latter films are concerned with the collision of mythological with modern, or specifically rational, consciousness. Medea deals less with the personality differences of two individuals than with a transition in human consciousness on a large scale:

As the story develops around Jason, it generates, as well, a changing image of the role and functions of narrative in human history: from that of reconciling man with nature to that of impelling the growth of the individual from collective to personal consciousness. (Snyder 95)

The crisis confronting Jason, which is akin to the dilemma found in Notes, is how are we to operate in the world with the freedom gained from the birth of reason without sacrificing the spiritual vision of reality inspired by the old religion? How can one reconcile the mystical and the rational?

In his Notes, Pasolini attempts to find a solution: "I feel I can recognize some analogies between the situation of the Oresteia and the situation of Africa today especially concerning the transformation of the Furies into the Eumenides". From being the goddesses of ancestral terror they are transformed into what Pasolini terms as "dreams of the irrational element that still remains alongside the rational democracy of the new state." And again:

The Furies who dominated the whole first part of the tragedy as Goddesses of a Tradition - a Tradition which was, precisely, full of blood and permeated by terror - are not destroyed at the end by the Goddesses of reason but transformed. Thus they remain irrational and archaic divinities; but instead of inspiring atrocious, obsessed, and de- 
grading dreams, they reign over works of poetry, of affective imagination. (Pasolini, in de Giusti 80)

The issue that Pasolini does not seem to resolve is whether, in fact, this 'marriage' can be. The paradox in Notes is that on the one hand, there is the pre-historic being, "the (neo-) exotic Other is itself an impossible dream, and the promise of transgression it offers is nothing more (but nothing less) than a matter of rhetoric" (Bongie 190-1). On the other hand, it is this Other which motivates Pasolini's attempt to project himself beyond his own corrupted society and to search for the sacred in the human.

What becomes important in all of his fictions is not their absolute truth but their operative value, the ability to generate holistic perception or individual growth. In this light, the similarity between Medea and Notes is even clearer: In Medea:

We pass through two stages of human history, a collision of forms of consciousness, and a bifurcation of perception engendered in the emergence of rational man. There is the implied sensibility that the universe is itself neither an absolute pantheon of gods nor a rational system but a creator or storymaker. Truths become useful fictions by which we live, different forms of fiction. [...] It is creative fantasy that fuels evolution and change, rather than, as one might expect in Pasolini, Marxist dialect. (Snyder 1002)

Notes therefore continues the narrative thread initiated with Edipo re and with $M e d e a$, a narrative which deals not only with the problems of a mythorientated consciousness, and not only with issues involving the individual's awareness of historical processes, but with the evolution of consciousness itself.

Bringing the myth of Orestes into the present, as he had done in the prologue and epilogue of Edipo re, Pasolini suggests myth's perpetuity beyond history, the circularity of man's experience, because life ends where it begins.

Mythology has to do with the stages of life, the process of transition and with the recognition of throwing off the old and entering the new. For Pasolini:

Africa is the embodiment of this process in the 20 th century. Myths are clues to the spiritual potentialities of the human life. [...] They are the experience of life. [...] These bits of information from ancient times have to do with the themes that have supported human life, [...] they have to do with deep inner problems, inner mysteries, inner thresholds of passage. (Campbell 4-5)

Pasolini makes the link between Athens and Uganda because Africa, for Pasolini, lives ambiguously somewhere between its irrational self and the 'rational' democratic state and because the birth of these two new nations have 
similar futures. When the Furies assail Orestes after the murder, Apollo, his god, speaks to him: "Flee and never grow weary and if they seek you wherever you go, never grow weary of the suffering you must undergo before you reach the land of Athena." Like Orestes assailed by the Furies whom he eventually overcomes, Africa will be assailed by "sofferenze" which, however, can lead to survival and (new) life:

Nulla muore mai in una vita. Tutto sopravvive. Noi, viviamo e sopravviviamo. Così anche ogni cultura è sempre intessuta di sofferenze. (Pasolini, Le belle bandiere 170) [Nothing ever dies in life. Everything survives. We, we live and we survive. So too every culture is always interwoven with sufferings].

This is the mythical idea of suffering and sacrifice which gives rise to the spiritual potentialities of human life and to rebirth. In Notes, Pasolini has the Oresteia sung in an idiom of jazz by black Americans for they embody the contradiction of the primal rhythm reconstructed within neo-capitalistic influence. Jazz is the primal rhythm reborn in an American society: often it is about loss and pain but ultimately it tells of life and survival. Pasolini chooses black Americans in particular because they encapsulate the alienated person, the sadness, but also the need for expression. Thus the use of jazz sung by black Americans is his attempt to poeticise their place in the new world. As Pasolini says in Notes:

Problems must be lived and life is slow. The proceeding towards the future is without any temporal break. The labour of the people knows no rhetoric and no pause. Its future lies in its eagerness for a future and its eagerness is also a great patience [...] and in the Africans, there is a great freedom and openness towards the future.

Orestes is judged. The Furies accuse him in the name of the archaic, religious world. But Athena chooses to defend him and Orestes is absolved. And so this is the story of the young man who leaves the world of his father, who experiences the modern world of courts and cities, who is driven by a need for knowledge and who must come to know a world different from his own. In the interviews, in Notes, with black Rome University students ${ }^{10}$, who like Orestes, have left their ancestral world, Pasolini's contradictory thoughts raise their head, once again, when he challenges his students: "Coming like Orestes to a modern world, you can learn something new and positive, but are you sure that what you learn in the western world is positive and that what you left is negative?"

This question is indicative of Pasolini's own paradoxical relationship with the mythical past and the modern present, but it also reinforces Pasolini's invitation to pursue agents of rationality and not to be a primitive mind afraid of understanding itself; it is an invitation to self-reliant thought, to assume the 
force of rational power and responsibility into oneself. An awareness of one's identity, being in touch with the historical moment, in Pasolinian terms, is what the transition to rational consciousness entails: "there are moments in history when one cannot be innocent, one must be aware; not to be aware is to be guilty" (Pasolini, in Stack, 31). The danger of refusing to aspire to selfknowledge is embodied by Oedipus in the earlier Edipo re: he remains lost in a state of consciousness both pre-Christian and outside historical process. One thinks of the final lines of Pasolini's poem "L'appennino":

he shuts his eyelids

in ignorance, and is lost in a people

whose clamor is nothing but silence. (Snyder 93)

And so, too, Medea's final words in Medea, "Nothing is possible anymore", testify to her inability to grow and to carry forward the narration of her own life.

In Notes, however, Pasolini still maintains the dream that the African Orestes can confront Western knowledge with an original spirit of his own which keeps the things he learns from being mere notions for consumption and makes them his own personal ideas: "Art is not entirely metahistorical, for the human story changes radically in cultures of different consciousnesses" (Snyder 101).

Notes ends with the transformation of the Furies into the Eumenides. This transformation would seem to represent the rebirth of the greater part of African states of the 1960 s into modern states, and the ideal that the new Africa can be a synthesis of the modern (rational) with the ancient (irrational). The Furies, the goddesses of irrationality agree to coexist with Athena, the goddess of reason, in the new democratic world and as Eumenides, they will control every human relationship.

However, Pasolini, for footage of this transformation, paradoxically shoots frenzied tribal dances, the performance of rites and a religious wedding - all signs of an ancient, magical world and an independent spirit which ironically contrast with the image of a new democratic world. Bongie suggests that the Third World's "cohabitation (convivenza) with history is nothing more than a phantasmic one, an imaginary relation between the real and the unreal" and that

to bestow upon the prehistoric a real content would be to betray its originary force. It would, we can add, be to grasp (fetishistically) what is by essence ungraspable. (Bongie 197-98)

Although the Third World and its essential difference from capitalism continued to fascinate Pasolini right up to his death, from a later, more retrospective and disappointed viewpoint, Pasolini aborts his effort at "making the decolo- 
nialized Other talk" and abandons "the attempt at giving literary expression to this endangered idea" by sidestepping "the conclusions to be drawn from his failed encounter with the Third World" (Bongie, 191).

However, what is important is that this particular work is significant as a part of Pasolini's ideological transitions. I would argue that Pasolini's attempt to make sense of the archaic world within the birth of rationalism and capitalism, and the apparent failure of this attempt, has a significant impact on the evolution of his genre and subsequent works, especially the films of the Trilogia della vita. ${ }^{.1}$ Snyder's view, although with reference to Medea, echoes my sentiment towards Notes:

To suggest that the film promotes a fictive or nonabsolute sense of reality is not to condemn it, but rather to locate it more firmly in a contemporary world view in which no absolute reality has been discovered behind the phenomenal world, and truth, at least since Nietzsche, has been seen to be a function of our life goals. (101)

In the conclusion of Notes (as in the Oresteia itself), the new world is established. The power to decide one's own future and to choose to expand one's soul through continued exploration is the alternative which Pasolini offers against the bourgeois consumer world.

When Pasolini wrote Le ceneri di Gramsci in 1957, it seems he was already aware that his transgressive dream of an innocent state, uncontaminated by capitalistic prerogatives, would collapse:

Come i poveri povero, mi attacco come loro a umilianti speranze, come loro per vivere mi batto ogni giomo. Ma nella desolante mia condizione di diseredato, io possiedo: ed è il più esaltante dei possessi borghesi, lo stato più assoluto. Ma come io possiedo la storia, essa mi possiede; ne sono illuminato: ma a che serve la luce? (Macafee and Martinengo 12)

[Poor as the poor I cling, like them, to humiliating hopes; like them, each day I nearly kill myself just to live. But though desolated, disinherited I possess (and it's the most exalting bourgeois possession of all) the most absolute condition. But while I possess history, it possesses me. I'm illuminated by it; but what's the use of such light?] (Macafee and Martinengo 13) 
The futility expressed in this last line is hauntingly summed up by Ferdinando Camon: "Era difficile ieri credere a Pasolini, perché scavalcava la storia. È comodo credergli oggi, quando la storia lo ha scavalcato" [It was difficult yesterday to believe Pasolini, because he went beyond history. It is easier to believe him today, when history has gone beyond him].

In Pasolini's own words, with reference to his subsequent films such as the Trilogia della vita:

Li ho fatti per opporre al presente consumistico un passato recentissimo dove il corpo umano e i rapporti umani erano ancora reali, benché arcaici, benché rozzi, però tuttavia erano ancora reali, e opponevano questa realtà all'irrealtà della civiltà consumistica. Ma anche questi film sono stati in un certo senso superati, resi vecchi dalla tolleranza della società dei consumi. (Naldini 348)

II made them in order to oppose the consumer present with a very recent past where the human body and human relationships were still real, although archaic, although coarse, however they were still real, and with this reality they opposed the irreality of the consumer civilisation. But even these films were in a way surpassed, made out-ofdate by society's tolerance of consumer goods].

\section{University of the Witwatersrand}

\section{NOTES}

1 A first version of this paper was read at the VIII International Congress of the Association of Professional Italianists, Cape Town, 6-8 September 1993.

2 I will be quoting from the English-dubbed video version entitled Noles for an African Orestes, from hereon referred to as Notes. In the credits of this version, however, there is no reference to who has translated from the Italian into English, nor is there a reference to whose voice is used in the voice over.

3 All unreferenced quotations are taken from these "audio-visual notes for a proposed film that would never be made" (Viano 250) which constitute Notes.

4 Some other examples include: Sopraluoghi in Palestina (1964); Appunti per un film sull' India (1968); a collection of articles entitled L'odore dell' India (1974); a screenplay for an unrealised film: Il padre selvaggio (1975).

5 All translations from the Italian are my own.

6 The title of a novel which Pasolini wrote in 1962, centering on the stark class confrontation between protesting peasant labourers and big landlords.

7 "Despite the availability of this film [Notes for an African Orestes], it has, to my knowledge, never been shown commercially in America as of the writing of this book" (Snyder 195).

8 Bongie, however, asks: "How can one recuperate "elsewhere' what civilization is in the process of eliminating if this same process has already taken on global proportions?" (5).

9 Pasolini translated Aeschylus' Oresteia into Italian: Orestiade.

10 The students' responses in the interview are spoken either in French or Italian with subtitles in English.

11 Decameron (1971); The Canterbury Tales (1972); Il fiore delle mille e una notte (1974). 


\section{WORKS CITED}

Bongie, Chris. Exotic Memories. Stanford: Stanford UP, 1991.

Camon, Ferdinando. "Applaudono Pasolini ma la storia l'ha superato." Tuttolibri aprile 1993: 848.

Campbell, Joseph. The Power of Myth. New York: Doubleday, 1988.

de Giusti, Luciano, ed. Pasolini. Cinema in forma di poesia. Pordenone: Cinemazero, 1979.

Falaschi, Giovanni. ed. Pier Paolo Pasolini. I dialoghi. Roma: Editori Riuniti, 1992.

Golino, Enzo. Il sogno di una cosa. Bologna: 11 Mulino, 1985.

Greene, Naomi. Pier Paolo Pasolini: Cinema as Heresy. Princeton: Princeton UP, 1990.

Lowell, Robert. Trans. The Oresteia of Aeschylus. London: Faber, 1979.

Macafee, Norman, and Luciano Martinengo, trans. Pier Paolo Pasolini. Poems. New York: Random House, 1982.

Naldini, Nico. Pasolini, una vita. Torino: Einaudi, 1989.

Pasolini, Pier Paolo. Orestiade. Torino: Einaudi, 1960.

-.Il sogno di una cosa. Milano: Garzanti, 1962.

. Sopraluoghi in Palestina, documentary film, Arco Film, 1964.

. Appunti per un film sull' India, documentary film, RAl, 1968.

L'odore dell' India. Milano: Longanesi, 1974.

Il padre selvaggio. Torino: Einaudi, 1975.

Le poesie. Milano: Garzanti, 1975.

Le belle bandiere. Ed. Gian Carlo Ferretti. Roma: Editori Ruuniti, 1977.

Il caos. Ed. Gian Carlo Ferretti. Roma: Riuniti Editori, 1979.

Notes for an African Orestes. Mystic Fire Video, 1989.

Santato, Guido. Pier Paolo Pasolini. L' Opera. Vicenza: Neri Pozza, 1980.

Siciliano, Enzo. Pasolini. Trans. John Shepley. London: Bloomsbury, 1987.

Snyder, Stephen. Pier Paolo Pasolini. Boston: Twayne, 1980.

Stack, Oswald. Pasolini on Pasolini: Interviews with Oswald Stack. Bloomington: Indiana UP, 1969.

Viano, Maurizio. A Certain Realism. Berkeley/Los Angeles/London: U of Califomia P, 1993. 